\title{
Statistical Analysis of Urban Growth in Kano Metropolis, Nigeria
}

\author{
Adzandeh Emmanuel Ayila ${ }^{1}$, Fabiyi O. Oluseyi ${ }^{1}$, Bello Yakasai Anas ${ }^{2}$ \\ ${ }^{1}$ Regional Centre for Training in Aerospace Surveys (RECTAS), OAU Campus, Ile-Ife, Osun State \\ ${ }^{2}$ Ministry of Land and Physical Planning, Dr Bala Mohd Road, Kano State \\ Email address: \\ ayilaj@rectas.org (A. E. Adzandeh), fabiyi@rectas.org (Fabiyi O. O.), anasbyakasai@gmail.com (Bello. Y. A.)
}

\section{To cite this article:}

Adzandeh Emmanuel Ayila, Fabiyi O. Oluseyi, Bello Yakasai Anas. Statistical Analysis of Urban Growth in Kano Metropolis, Nigeria. International Journal of Environmental Monitoring and Analysis. Vol. 2, No. 1, 2014, pp. 50-56. doi: 10.11648/j.ijema.20140201.16

\begin{abstract}
Understanding and quantifying the spatio-temporal dynamics of urban growth in Kano Metropolis is necessary to put forward appropriate policies and monitoring strategies so as to make informed decision. The city has witnessed growth and infrastructural development such as low cast housing estates, highways and markets, to mention a few. This study examines the growth of Kano, Nigeria between 1986 and 2005 using remote sensing technology. Markov chain model was employed to predict future land use land cover in the area. Landsat images of 1986, 2000 and 2005 were classified into four land cover classes. Image classification analysis showed a rapid growth in built up land between $13.2 \%$ in 1986 to $19.3 \%$ in 2005 and an annual rate of change of $1.51 \%(1986-2000)$ and $1.24 \%$ (2000-2005). The period witnessed a reduction in vegetal cover from $33.9 \%$ by the year 1986 to $13.6 \%$ in 2005 . Range land was recorded to occupy an average area of $56.4 \%$ in the 3 periods put together. It was also observed that change by 2015 will follow almost the same trend in the period studied with the built up area projected to cover $(21.70 \%)$ of the total land area. The findings. The study indicated that in the last 19 years the built up area is increasing in size, and this have impact on the natural environment.
\end{abstract}

Keywords: Analysis, Growth, Kano metropolis, Remote Sensing

\section{Introduction}

Urban land use/land cover changes are very dynamic in nature and have to be monitored at regular intervals for sustainable environment development [15]. Urbanization is the process of population concentration in a location due homocentric pulling factors. Urban growth or sprawl is simply the expansion of towns and cities. According to [3] urban growth is a spatial and demographic process and refers to the increased importance of towns and cities as a concentration of population within a particular economy and society. Many town and cities in developing countries have withnessed high growth rate in recent time.

There is strong effects of land use and land cover changes on our environment today. The natural environment of West Africa like most parts of the world is constantly experiencing change. Landuse change affects the socio-economic conditions of an environment $[5,17]$. The growth of most Nigerian cites in recent times, especially Kano has been sporadic. Nigeria, by her population figure of 140 million in 2006 is considered the highest in sub-Saharan African, with a complex growth of settlement $[8,1]$. As a result of rural-urban migration, Nigeria like other parts of developing countries is experiencing challenges of rapid urbanization and sustainability [13, 20]. Urban sprawl in Lagos for example has put profound pressure on housing, infrastructure, and the environment $[11,2]$. It is therefore necessary to investigate the dynamics of city growth in Nigeria and Kano metropolis in particular. Currently, there is no up-to-date comprehensive documentation on trend and magnitude of land use pattern dynamics in Kano metropolis. The natural land cover in the area have changed over time and still experiencing change. Natural and anthropogenic factors have impacted on the environment. The social and environmental repercussion of loosely planned urban cities could be catastrophic especially in the present situation in cities that has constantly experienced remarkable urban expansion in a short period of time [10]. Predicting and understanding urban growth and change are critical to city planners and resource managers especially in rapidly changing environments $[18,4]$.

Understanding and quantifying the spatio-temporal dynamics of urban growth in Kano metropolis is necessary to put forward appropriate policies and monitoring strategies 
so as to make informed decision. The city has witnessed growth and infrastructural development such as low cast housing estates, highways (figure 1) departmental stores and large markets, to mention a few. The objectives of the paper are to: (i) analyze growth in Kano metropolis between 1986 and 2005 using the techniques of Remote Sensing; (ii) examine the spatial pattern of land use land cover in the area; and (iii) determine the rate of expansion and project future growth.

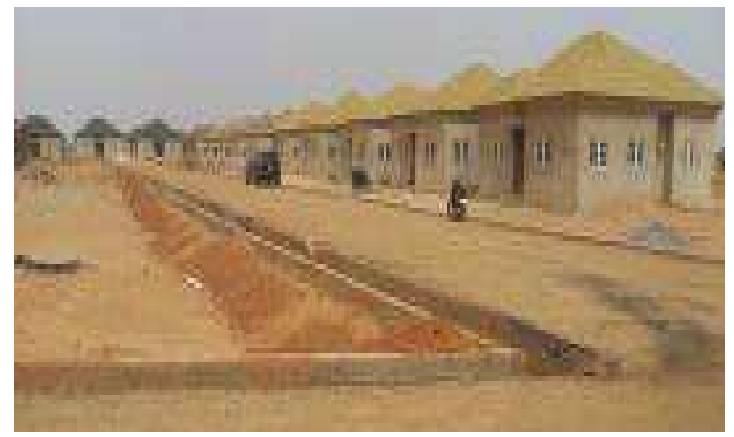

(a)

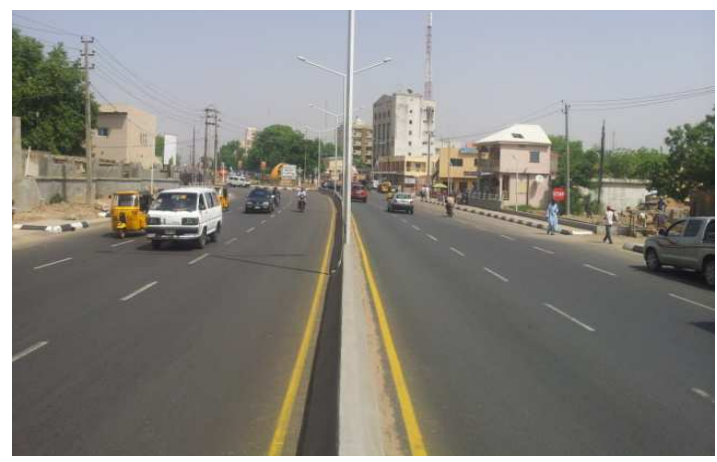

(b)

Figure 1. (a) New Housing Estate constructed by the State government (2013): Decongestion of Urban Centre; (b) Expansion of Roads in the study area

\subsection{The Study Area}

The study location is Kano metropolis, Nigeria (figure 1). It is situated between latitudes $11^{\circ} 25^{\prime} \mathrm{N}$ to $12^{\circ} 47^{\prime} \mathrm{N}$ and longitude $8^{\circ} 22^{\prime}$ E to $8^{\circ} 39^{\prime} \mathrm{E}$ east and $472 \mathrm{~m}$ above sea level. Kano metropolis is bordered by Madobi and Tofa Local Government Areas (LGAs) to the South West, Gezawa LGA to the East, Dawakin Kudu LGA to the South East, and Minjibir LGA on the North East. The study area is made up of eight (8) LGAs. They include Dala, Fagge, Gwale, Kano Municipal, Nassarawa, Tarauni and parts of Ungogo and Kumbotso local governments. Kano metropolis is the third largest town in Nigeria after Lagos and Ibadan. It has a population of 2,826307 people [15]. Kano is referred to as the Center of Commerce in the Country due to long flourished marketing activities. This is based on the fact that marketing and trading has been the dominant economic activity of the Populace of the Metropolitan Kano. However, the land is mostly exploited by urban agriculture through waste water utilization to sustain daily needs.

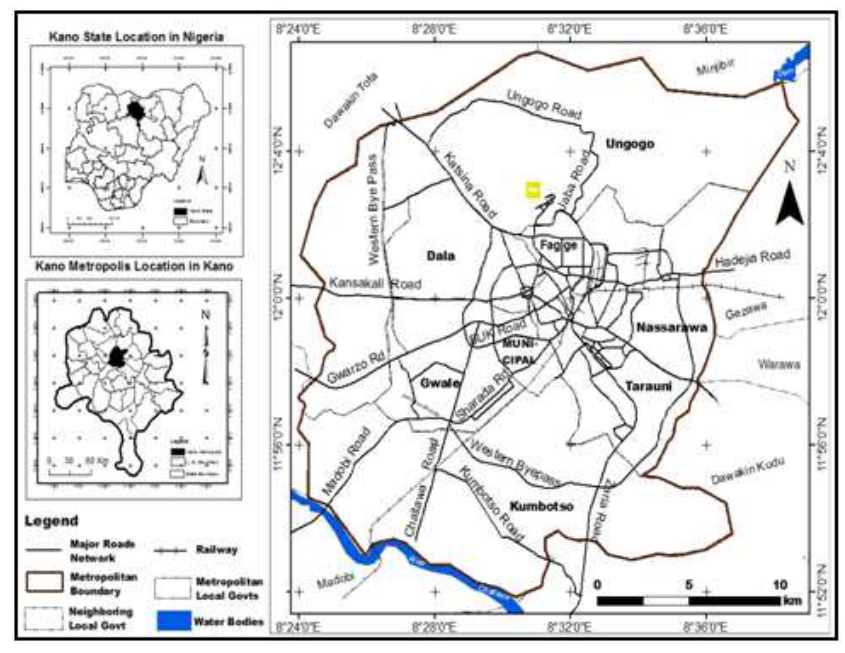

Figure 2. Map of Kano Metropolis

The climate of the area is influenced by the movement of the two air masses, the maritime air masses originating over Atlantic Ocean and the dry air masses coming from the Sahara desert. Consequently, the area is characterized by wet season (May - September) which is characterized by south western maritime winds that carry warm and humid air; the dry season (October - April) is characterized by the tropical dry continental wind (Harmattan) from north. The average temperature is a bit hot, even during the cool Harmattan period the minimum temperature hardly falls below $11^{\circ} \mathrm{C}$, whilst the monthly average temperature is not less than $20^{\circ} \mathrm{C}$, whereas during the hot season usually Mid - March to Mid-May, the maximum temperature reading may be as high as $40^{\circ} \mathrm{C}$. The average temperature for these hot months may range between $30^{\circ} \mathrm{C}$ and $32^{\circ} \mathrm{C}$.

\section{Materials and Method}

The study made use of Landsat satellite images of Kano State for 1986, 2000 and 2005. Imagery for the three (3) dates used were acquired from Global Land cover Facility (GLCF) website. The focus here was to carry out change detection. There are many types of change detection methods of multi-spectral image data. They can be classified as three categories: characteristic analysis of spectral type, vector analysis of spectral changes and time series analysis. The most popular is the time series analysis, whose aim is to analyze the process and trend of changes by monitoring ground objects based on remote sensing continuous observation data [5].

Four spectral classes were identified in the images acquired. They include vegetal cover, bare ground, range land, and built-up areas. This was based on the Landsat pathfinder classification scheme (see Table 1) [12]. Using the IDRISI Software, the image data was classified for change detection. The algorithm analysis generated statistics used to estimate the rate, extent and pattern of urban growth in Kano metropolis. Other workers [7, 9, 19, and 14] have used similar method. 
Table 1. Classification scheme adopted from USGS [12]

\begin{tabular}{lll}
\hline Land Cover & 432 Appearance & Definition \\
\hline Barren land & Shades of Green & $\begin{array}{l}\text { Sandy areas, rocks, outcrop, } \\
\text { untarred roads, open country } \\
\text { Grass land and generally light } \\
\text { vegetated areas }\end{array}$ \\
Fonge land & Pink & $\begin{array}{l}\text { Forest cover and deeply } \\
\text { vegetated areas } \\
\text { Settlements, urban area, and } \\
\text { urban related features }\end{array}$ \\
Built-up land & Cyan-Blue & \\
\hline
\end{tabular}

The image classification was generally based on ground truth sample points and pre-established spatial pattern. At the post interpretation stage of the exercise, accuracy assessment was carried out. Preliminary maps were validated and adjusted based on base map, ground truth information and GPS observation carried out. The results of the land use change and trajectory analysis are disscussed in the next section.

To analyze trend, a table showing the area in hectares and the percentage change for each year (1986, 2000 and 2005) measured against each land use land cover type was developed. Percentage change to determine the trend of change was then calculated by dividing observed change by sum of changes multiplied by 100 .

$$
\text { (Trend) percentage change }=\mathrm{X} / \mathrm{Y} * 100
$$

Where $\mathrm{X}$ is the observed change and $\mathrm{Y}$ is the sum of change.

In obtaining annual rate of change, the percentage change is divided by 100 and multiplied by the number of study year 1986 - 2000 (4years) 2000 - 2005(5years).

Reclassification and Raster calculation operations were used to identify changes in the area of built-up.

First was to reclassify the land cover of the three years into two, Built-up (coded 1) and other land covers (coded 0 ). Raster Calculator was then used to add the three reclassified images to determine the expansion of built-up in four scenarios (Table 2).
Future expansion was predicted using Markov Chain and Cellular Automata. A Markovian process is one in which the future state of a system can be modeled purely on the basis of the immediately preceding state. Markovian chain analysis will describe land use change from one period to another and use this as the basis to project future changes. This is achieved by developing a transition probability matrix of land use change from time one to time two, which shows the nature of change while still serving as the basis for projecting to a later time period .The transition probability may be accurate on a per category basis, but there is no knowledge of the spatial distribution of occurrences within each land use category. Hence, Cellular Automata (CA) was used to add spatial character to the model.

Table 2. Urban Expansion Interpretation

\begin{tabular}{lllll}
\hline $\mathbf{1 9 8 6}$ & $\mathbf{2 0 0 0}$ & $\mathbf{2 0 0 5}$ & $\mathbf{1 9 8 6}+\mathbf{2 0 0 0}+\mathbf{2 0 0 5}$ & Interpretation \\
\hline 0 & 0 & 0 & 0 & No Built up \\
1 & 1 & 1 & 3 & Built since 1986 \\
0 & 1 & 1 & 2 & Expansion 2000 \\
0 & 0 & 1 & 1 & Expansion 2005 \\
\hline
\end{tabular}

\section{Results and Discussion}

Supervised image classification of Landsat data for three dates (1986, 2000 and 2005) of the environment were analyzed for urban growth in Kano metropolis. Pictures of some areas where barren land and rang land have been converted or used for the construction of new cities and roads are shown in figures 3-5. The LULC distribution of area for the 3 Periods is shown in Table 3 . The table reveals that Forest land (vegetal cover) loss to the other land cover classes from $33.9 \%$ to $13.6 \%(1986-2005)$. Build up appreciated within the study period from $13.2 \%$ to $19.3 \%$. Rang land occupies an average of $56.4 \%$ of the area in 3 period put together. Land cover maps were produced for the period to show spatial structure (figures 6-8).

Table 3. LULC Distribution of Kano Metropolis (1986, 2000 and 2005)

\begin{tabular}{|c|c|c|c|c|c|c|}
\hline \multirow{2}{*}{ LAND COVER } & \multicolumn{2}{|c|}{1986} & \multicolumn{2}{|c|}{2000} & \multicolumn{2}{|c|}{2005} \\
\hline & AREA (Ha.) & AREA (\%) & AREA (Ha.) & AREA (\%) & AREA (Ha.) & AREA (\%) \\
\hline Barren Land & 1089 & 2.34 & 2572 & 5.52 & 3506 & 7.52 \\
\hline Range Land & 23282 & 49.94 & 27796 & 59.62 & 27764 & 59.55 \\
\hline Forest Land & 15793 & 33.87 & 8150 & 17.48 & 6335 & 13.59 \\
\hline Built-up Land & 6459 & 13.85 & 8105 & 17.38 & 9018 & 19.34 \\
\hline Total & 46623 & 100 & 46623 & 100 & 46623 & 100 \\
\hline
\end{tabular}

Table 4. Annual rate of Change for: 1986, 2000 and 2005

\begin{tabular}{lllllll}
\hline LAND COVER & $\mathbf{1 9 8 6 - 2 0 0 0}$ & & $\mathbf{2 0 0 0 - \mathbf { 2 0 0 5 }}$ & & \multicolumn{2}{c}{$\begin{array}{l}\text { ANNUAL RATE } \\
\text { OF CHANGE }\end{array}$} \\
& $\begin{array}{l}\text { AREA } \\
\text { (Ha.) Change }\end{array}$ & $\mathbf{\%}$ of Change & $\begin{array}{l}\text { AREA } \\
\text { (Ha.) Change }\end{array}$ & $\begin{array}{l}\text { \% of Change } \\
\mathbf{1 9 8 6}-\mathbf{2 0 0 0} \\
\mathbf{( \% )}\end{array}$ & $\begin{array}{l}\mathbf{2 0 0 0}-\mathbf{2 0 0 5} \\
\mathbf{( \% )}\end{array}$ \\
\hline Barren Land & 1483 & 9.70 & 934 & 25.28 & 1.34 & 1.26 \\
Range Land & 4514 & 29.53 & -32 & -0.87 & 4.13 & -0.04 \\
Forest Land & -7643 & -50 & -1815 & -49.13 & -7 & -2.46 \\
Built-up Land & 1646 & 10.77 & 913 & 24.72 & 1.51 & 1.24 \\
Total Change & 15286 & 100 & 3694 & 100 & & \\
\hline
\end{tabular}




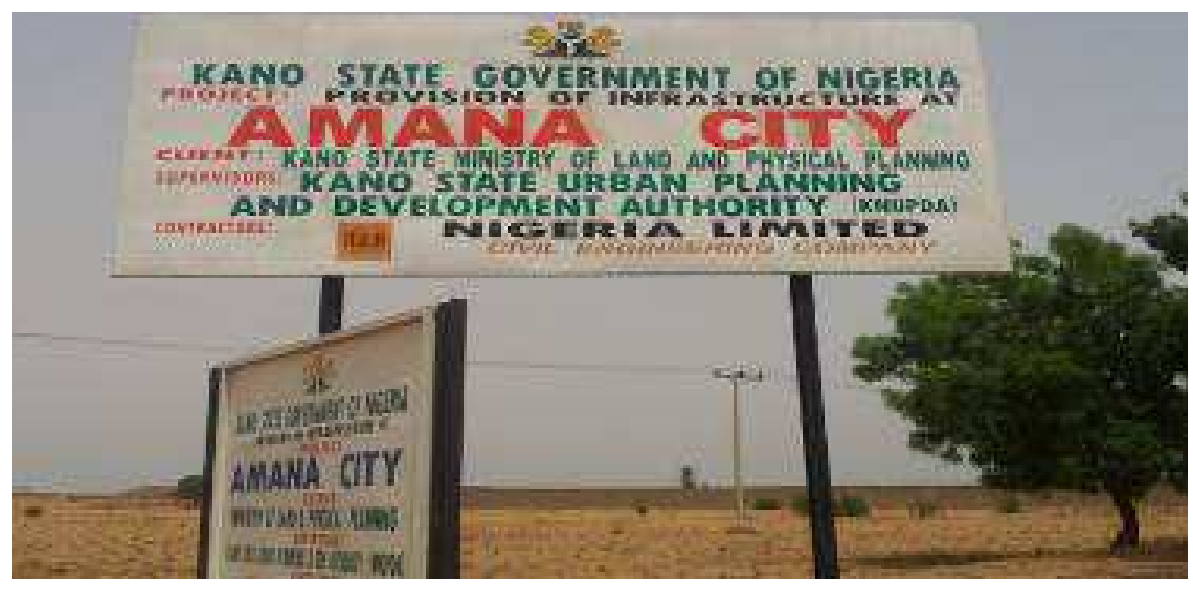

Figure 3. Kano new Mega City( One of the new cities to decongest Metroplitan area)

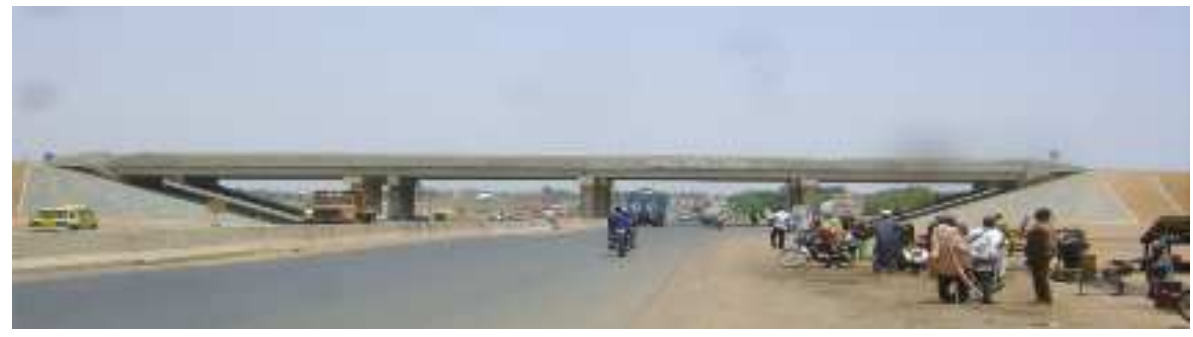

Figure 4. Newly constructed overhead bridge (linking Kano western bypass)

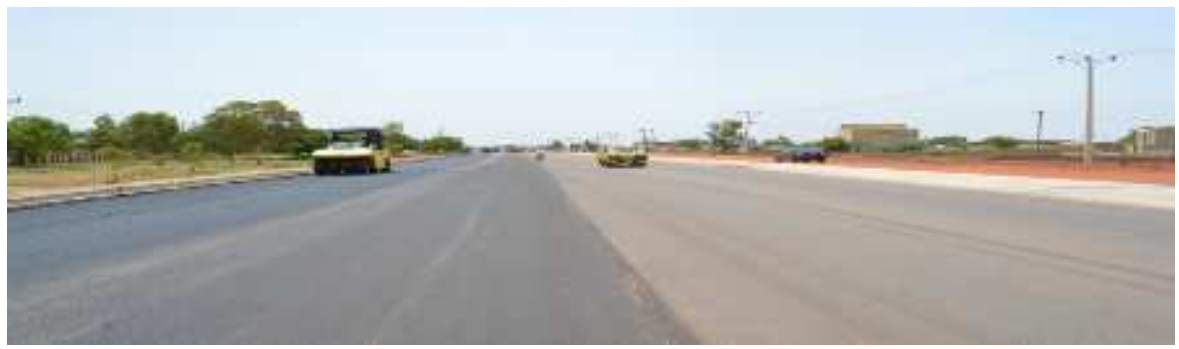

Figure 5. dualization of township Road (2013)

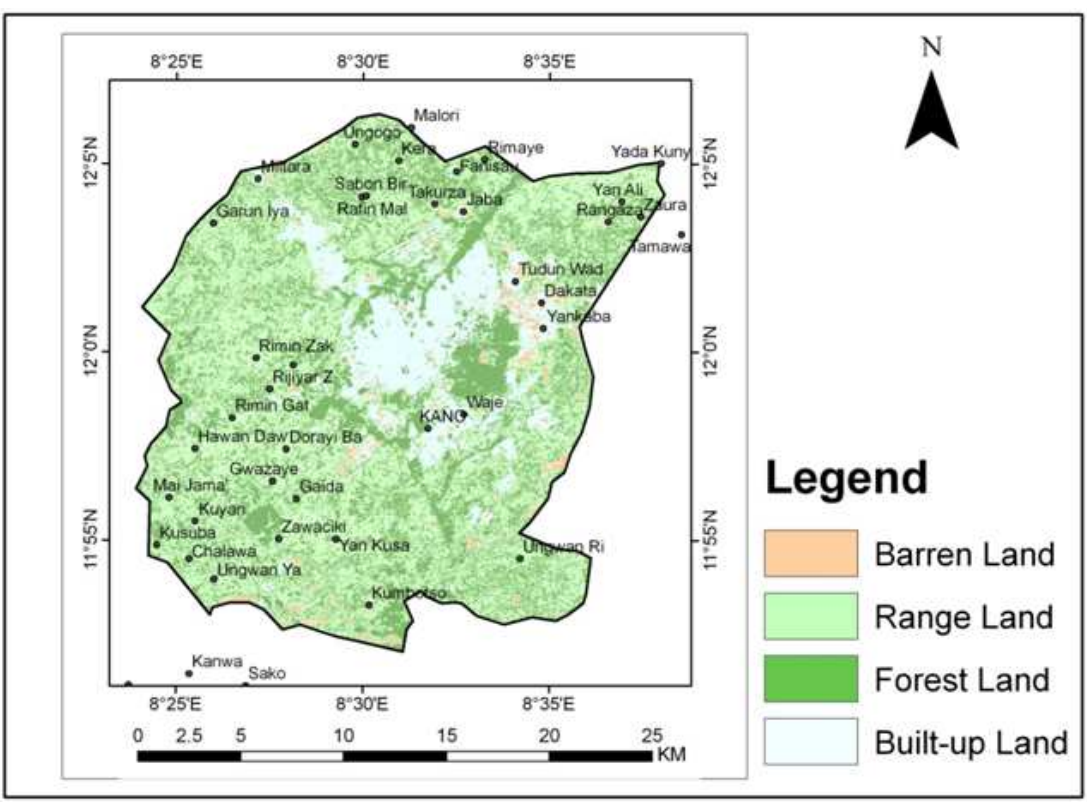

Figure 6. Land Cover derived from Landsat image of 1986 


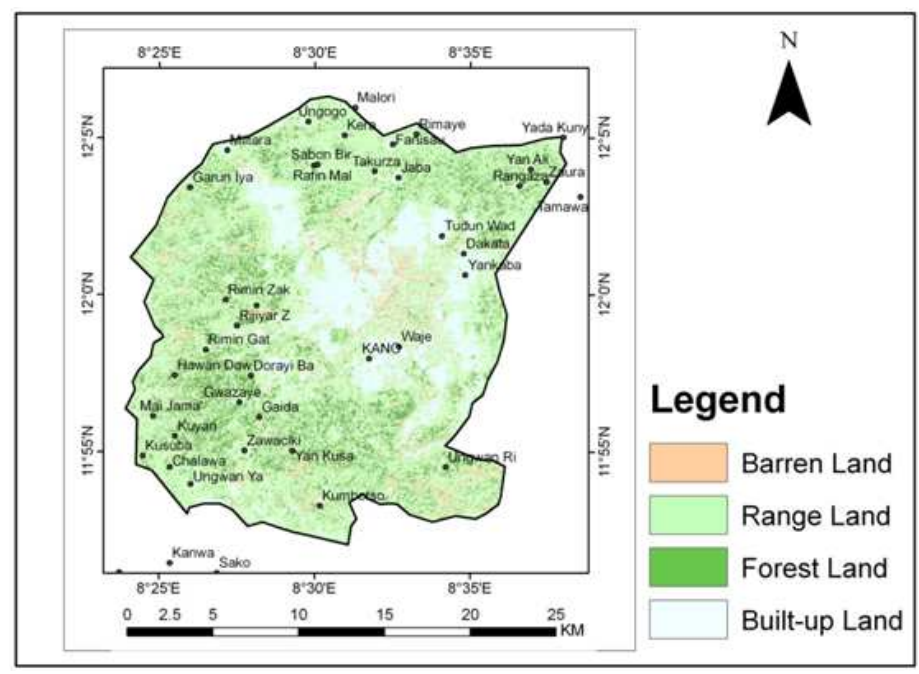

Figure 7. Land Cover derived from Landsat image of 2000

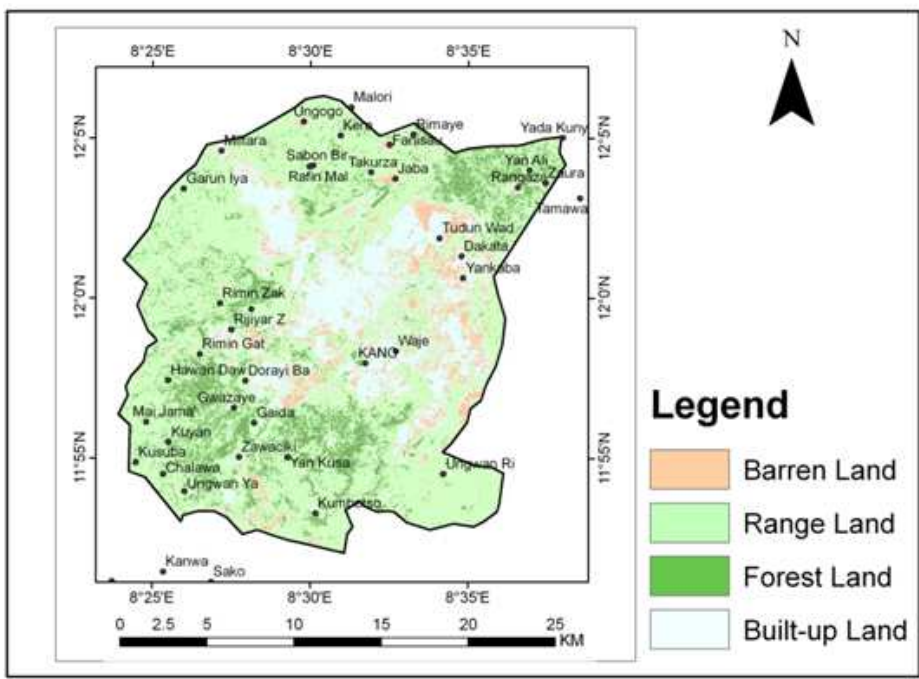

Figure 8. Land Cover derived from Landsat image of 2005

Change detection analysis (Table 4) reveals that between 1986 and 2000, barren land was (1433ha) representing $9.70 \%$ changes with an annual rate of $1.34 \%$. From 2000 to 2005 , the annual rate of change was $1.26 \%$. Built up gained with an annual rate of change of $1.51 \%$ (1986-2000) and $1.24 \%$ (2000-2005). There was remarkable decrease in annual rate of change in the forest land within the study area, the result shows that between 1986 to 2000 it was (-7\%) and $(-2.46 \%)$ in 2000 to 2005 . The comparison of Landuse landcover for 1986, 2000 and 2005 of Kano Metropolis (figure 9), shows that percentage change in land categories of the Metropolis is comparatively high due to rapid urbanization. The rapid urban growth can be attributed to migration of people from rural areas to the city either for labour or commercial activities.

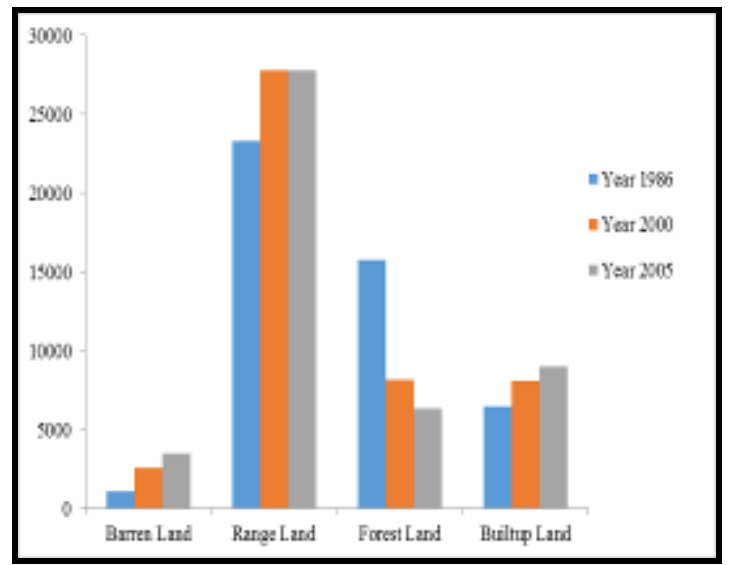

Figure 9. Trend of Land cover changes in Kano metropolis (1986-2005)

The nature and location of urban change process involved a pixel to pixel comparison of the study year images through overlay. In terms of location of change, the emphasis is on built-up land. The change between 1986 and 2005 is shown 
in figure 10. It was observed that the growth progress is moving away from the city center with more growth in the north particularly, the northwest of the city.

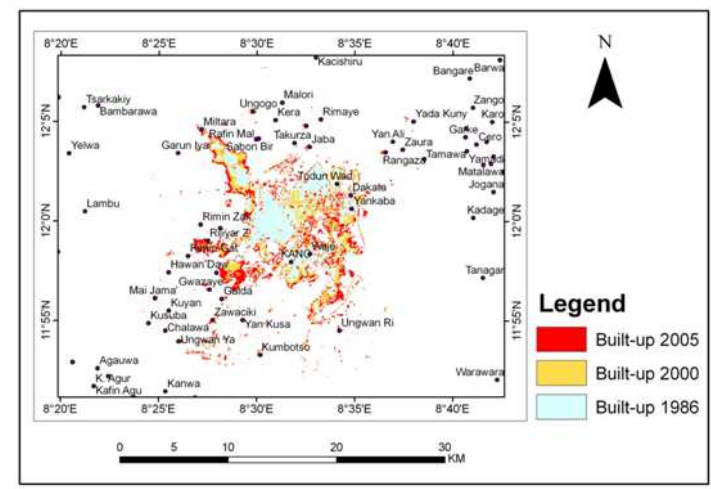

Figure 10. Urban Change Map 1986 - 2005

\subsection{Transition Probability Matrix (MARKOV) and Projection for 2015 (CA_MARKOV)}

The transition probability matrix which records the probability that each land cover category will change to the other category is presented in Table 5. This matrix is produced by the multiplication of each column in the transition probability matrix by the number of cells of corresponding land use in the later image. Row categories represent land use land cover classes in 2005 whilst column categories represent 2015 classes. As seen from the table, built up and barren land have 0.8521 and 0.6919 probability of remaining built up and barren land respectively which is a very high probability.

Land use/land cover prediction of the study area for 2015 was estimated (Table 6). It was observed that built up will occupy $21.70 \%$ of the total area while rangeland will also occupy $56.01 \%$ of the total area. Forestland and barren land has the probability of occupying $12.97 \%$ and $9.32 \%$ respectively. From the Markovian chain analysis performed to describe landuse changes from one period to another, taking into consideration the preceeding state (2005), the projected analysis revealed that range land will constitute $26112 \mathrm{Ha}$, which represent the highest share of (56.01\%) followed by Built-up land expected to cover 10119Ha and constitute $(21.70 \%)$ of the total area. Forest land from the analysis is projected to cover $6047 \mathrm{Ha}(12.97 \%)$ of the study area, and lastly Barren land which will occupy $4345 \mathrm{Ha}$ (2.34\%) representing the least coverage. Figure 7 is the CA Markov Land Cover Prediction map for the year 2015.

Table 5. Transition Probability Matrix

\begin{tabular}{lllll}
\hline & $\begin{array}{l}\text { Barren } \\
\text { Land }\end{array}$ & $\begin{array}{l}\text { Range } \\
\text { Land }\end{array}$ & $\begin{array}{l}\text { Forest } \\
\text { Land }\end{array}$ & $\begin{array}{l}\text { Built-up } \\
\text { Land }\end{array}$ \\
\hline Barren Land & 0.6919 & 0.1836 & 0.0000 & 0.1645 \\
Range Land & 0.0400 & 0.7268 & 0.1808 & 0.0523 \\
Forest Land & 0.0300 & 0.7440 & 0.1621 & 0.0639 \\
Built-up Land & 0.0841 & 0.0638 & 0.0000 & 0.8521 \\
\hline
\end{tabular}

Table 6. Projected Land use land cover for 2015

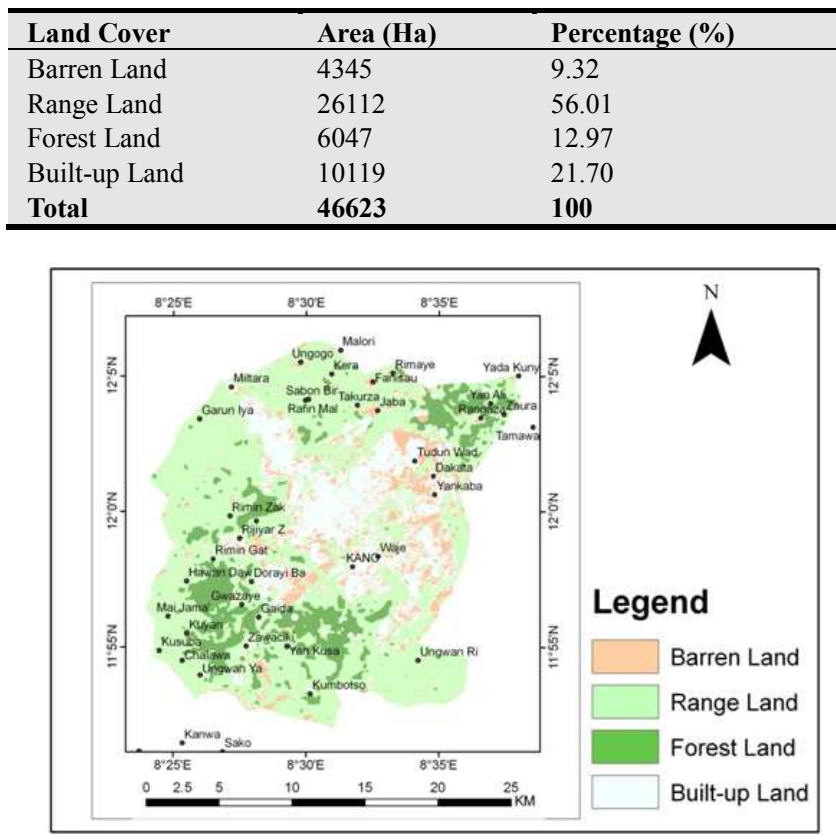

Figure 11. CA Markov Land Cover Prediction Map for 2015

It is clear from this study that the urbanization of Kano Metropolis is attributed to several factors which apart from being a State capital, increase in population through natural birth, siting of educational institutions, immigration and the location of industries/ large Markets. However, the occasional and remote physical expansion (urbanization) could endanger the forestlands and environmental ecologies in and around the City periphery. By means of integrated use of remote sensing and GIS data, timely decisions could be taken to both control the development plan, open space, social infrastructure and prevent the unfavorable features like sprawls in the area.

\subsection{Conclusion}

This paper examined the use of Remote Sensing technology in mapping Land Use Land Cover in Kano metropolis between 1986 and 2005. Four land cover classes namely built-up, forest land, range land, and barren land were classified. The analysis showed a rapid growth in built-up land between 1986 and 2005 (13.85\% to 19.34\%) while the period witnessed a reduction in vegetation (33.87\% to $13.59 \%)$. It was also observed that the built-up land cover of Kano metropolis by 2015 may likely have appreciated to $21 \%$. This is a significant figure when compared to the $10 \%$ it was in 1986 . It was also discovered that Metropolitan Kano has been undergoing remarkable urban expansion. The growth in built up was prolonging both from urban centre to adjoining non-built up areas in all direction, but mainly to Gwarzo and Zaria road axis.

It is also worthy to note that, the driving forces behind the rapid expansion of Kano is that the State being the largest commercial centre in Northern Nigeria, with about 10 million people, (according to the 2006, NPC census figure) 
provides a stable and continues market for both manufactured and semi-processed goods. The volume of trading activities conducted on daily basis in the markets, notably Muhammadu Abubakar Rimi (Sabon -Gari), Kwanar Singer, Kantin Kwari, Kurmi and Dawanau markets signify the state's great potentials as a market for various products. It is the second largest industrial centre in Nigeria and the largest in the Northern Nigeria. There are at present over 400 privately owned medium and small scale industries in the state producing various items, such as textile materials, tanned leather, foot wears, cosmetics, plastics, enamel ware, pharmaceuticals, ceramics, furniture and bicycles. Others include agricultural implements, soft drinks, food and beverages, dairy products, vegetable oil, animal feeds etc.

\section{References}

[1] A. Jiboye, "Sustainable urbanization: issues and challenges for effective urban"2011. Accessed: 17/07/2012. Retrieve from: www.ccsenet.org/jsd.

[2] A.K., Braimoh, and T. Onishi, 'Spatial determinants of urban land use change in Lagos', in Cheng, J., 2003. Modelling spatial and temporal urban growth. Enschede. NL ITC: 203. (2007).

[3] B. Bhatta, S. Saraswati, and D. Bandyopadhyay, "Quantifying the degree-of-freedom, degree-of-sprawl, and degree-of-goodness of urban growth from remote sensing data". Elsievier Journal of Applied Geography, 2010. 30. P96 -111 .

[4] B.L., Turner, R.H., Moss, and D.L. Skole, 'Relating land use and global land cover change: A proposal for an IGBP-HDP core project'. International-Geosphere- Biosphere Program, IGBP Report No. 24, HDP Report No:5. 1993. Stockholm: Royal Swedish Academy of Sciences.

[5] C. Mundia, M. Aniya, "Dynamics of landuse/cover changes and degradation of Nairobi city, Kenya". Land Degrad. Develop. 2006. (17): 97-108.

[6] D. Lu, "Land-cover binary change detection methods for use in the moist tropical region of the Amazon: A comparative study". International Journal of Remote Sensing, Vol. 26. 2005.

[7] D.N. Olayinka, P.C. Nwilo, A.S Adefarati., E.A. Adzandeh, and A. Atagbaza, 'Landuse Expansion and its Effect on Land Surface Temperature in Ifo Local Government Area of Ogun State. Nigeria Journal of Surveying and Geoinformatics. 2012. Vol. 4, No1. Pp 55-71. ISSN: 0189-8914.

[8] F. Ujoh, I.D. kwabe and O.O. IfatimehinUjoh, "Understanding urban sprawl in the Federal Capital City, Abuja: Towards sustainable urbanization in Nigeria", 2010. Accessed: 17/07/2012. Retrieved from http://www.academicjournals.org/JGRP.
[9] I.A. Jesuleye, R. Oyinloye, E.A. Adzandeh and E. Eguaroje, 'Geospatial Assessment and Monitoring of the Dynamics of Urban Expansion of Ogbomoso, South-Western Nigeria'. Research Journal of Environmental and Earth Sciences. Maxwell Science Publications. Accepted: May 03, 2013. In Press. Article \# 10867-RJEES-DOI.

[10] J.I. Barredo, L., Demicheli, Lavelle, C., Kasanko, M., \& N. McCormick, 'Modelling future urban scenarios in developing countries: An application case study in Lagos, Nigeria'. Environment and Planning B: Planning and Design, (2004). 32, 65-84.

[11] J.O. Abiodun, 'Urban growth and problems in metropolitan Lagos. Urban Studies, 1974. 11 (33), 341-347.

[12] J. R. Anderson, E.E. Hardy, J. T. Roach, \& R. E. Witmer, “A land use and land cover classification system for use with remote sensor data, Geological Survey Professional Paper 964". A revision of the land use classification system as presented in U.S. Geological Survey Circular 671, United States Government Printing Office, Washington, 1976.

[13] L. Lawanson, "Challenges of sustainability and urban development in Nigeria: Reviewing the millenium development goals", 2006. Accessed: 07/14/2012. Retrieved from www.unilag.edu.ng/opendoc.php?sno $=4241 \&$ doctype $=$ doc .

[14] M. Oyinloye, and O. Kufoniyi, 'Analysis of Landuse, Landcover Change and Urban Expansion inAkure, Nigeria'. Journal of Innovative Research in Engineering and Sciences, 2011. Vol 2(4), 234 -248.

[15] M. Mohan, "Urban Land use/land cover change detection in national capital region, Delhi: A case study of faridabad district. Cairo, Egypt". FIG working week, 2005.

[16] NPC, "Nigeria national population census report, 2006". Retrieved from: Nigeria Population Commission (NPC) office, Kano state.

[17] P. Krishna, B. Stinner, S. Deb, J. Cardina, R. Moore, K. Prabhat, T. Harao, T. Kiyoto, K. Badarinath, and H. Casey, "Trends in food production and nitrous oxide emissions from the agriculture sector in India: environmental implications". Regional Environmental Change. 2003. Vol.(3). no.4. pp. 154-161.

[18] P. L., Knox, 'The restless urban landscape. Englewood Cliffs, 1993. NJ: Prentice-Hall.

[19] R.O. Oyinloye, and F.A. Adesina, 'Some Aspects of the Growth of Ibadan and their Implications for Socio-economic Development'. Ife Social Sciences Review, 2006. Vol.20 No 1, pp 113-120.

[20] T. Danmole, "Sustainability and city development:a critique of the implementation of abuja masterplan" 2004. Accessed: 14/10/2012. Retrieved: from: www.unilag.edu.ng/opendoc.php?sno $=4242 \&$ doctype $=$ doc 